\title{
The influence of Facebook on Political Activism and Radicalism
}

\author{
Cleno Couto ${ }^{1}$ \\ João Gabriel Modesto ${ }^{1}$ \\ ${ }^{1}$ Centro Universitário de Brasilia, Brasilia, Distrito Federal, Brasil
}

\begin{abstract}
Recently, an increase in radicalism in the political sphere has ocurred. This study aimed to evaluate the influence of the intensity of Facebook use on political radicalism and activism, taking as hypothesis $\left(\mathrm{H}_{1}\right)$ that the intensity of Facebook use can increase radicalism and activism rates and $\left(\mathrm{H}_{2}\right)$ that this effect would be partially mediated by the degree of confidence in Facebook consumed information. To this end, 211 respondents participated by answering the Facebook Intensity Scale, Online News Consumption Confidence Scale and Activism and Radicalism Intention Scale. The results did not corroborate the mediation model $\left(\mathrm{H}_{2}\right)$ but only the direct effect $\left(\mathrm{H}_{1}\right)$, indicating that, regardless of user trust in the news they are accessing, the use of Facebook tends to favor higher rates of activism and radicalism. Implications of the findings are discussed.

Keywords: social media; social influence; political psychology.
\end{abstract}

A Influência do Facebook no Ativismo e Radicalismo Político

\begin{abstract}
Resumo
Recentemente tem sido noticiado um incremento do radicalismo no âmbito político. O presente estudo buscou avaliar a influência da intensidade de uso do Facebook no radicalismo e ativismo político, tendo como hipótese $\left(\mathrm{H}_{1}\right)$ que a intensidade do uso do Facebook pode incrementar os índices de radicalismo e ativismo e $\left(\mathrm{H}_{2}\right)$ que esse efeito seria parcialmente mediado pelo grau de confiança na informação consumida no Facebook. Participaram 211 pessoas que responderam à Escala de Intensidade de Uso do Facebook, Escala de Confiança no Consumo de Notícias Online e Escala de Ativismo e Radicalismo. Os resultados não corroboraram o modelo de mediação $\left(\mathrm{H}_{2}\right)$, mas apenas o efeito direto $\left(\mathrm{H}_{1}\right)$, indicando que, independente do usuário confiar na notícia que está acessando, o uso do Facebook tende a favorecer maiores índices de ativismo e radicalismo. Implicações dos achados são discutidas.
\end{abstract}

Palavras-chave: mídias sociais, influência social, psicologia política.

\section{La Influencia de Facebook en el Activismo y el Radicalismo Político}

\begin{abstract}
Resumen
Recientemente se ha comunicado un aumento del radicalismo en la esfera política. El presente estudio buscó evaluar la influencia de la intensidad del uso de Facebook en el radicalismo y activismo político, teniendo como hipótesis $\left(\mathrm{H}_{1}\right)$ que la intensidad del uso de Facebook puede incrementar los índices de radicalismo y activismo y $\left(\mathrm{H}_{2}\right)$ que ese efecto sería parcialmente mediado por el grado de confianza en la información consumida en Facebook. Participaron 211 personas que respondieron a la Escala de Intensidad de Uso de Facebook, Escala de Confianza en el Consumo de Noticias En Línea, Escala de Activismo y Radicalismo. Los resultados no corroboraron el modelo de mediación $\left(\mathrm{H}_{2}\right)$, sino sólo el efecto directo $\left(\mathrm{H}_{1}\right)$, indicando que, independientemente del usuario confiar en la noticia que está accediendo, el uso de Facebook tiende a favorecer mayores índices de activismo y radicalismo. Se discuten las implicaciones de los hallazgos.

Palabras clave: medios sociales; influencia social; psicología política.
\end{abstract}

It is noticeable, and often reported that, for some years now, a growth in radical action and hate speech in different political contexts has occurred (Antunes, 2016; Santana \& Silva, 2017). Among the possible reasons that favor such actions, the present study will analyze the influence of the intensity of Facebook use on political activism and radicalism.

Facebook is the most widely used social media in Brazil (We are social \& Hootsuite, 2018). It was founded in 2004 with an organizational mission of "bringing the world closer" (Facebook, n.d.). Despite this organizational mission, one of the aspects usually discussed about Facebook is the filter bubble, which can be defined as algorithmic information filtering mechanisms that, through your use of online services, can create a profile with your specific tastes and values (Pariser, 2012). These filters have the main characteristic of restraining the individual to a restricted information cycle, since they tend to favor contact with content corresponding to the user personal likes, values, beliefs and expectations (Antunes, 2016; Fava \& Pernisa Júnior, 2017; Pariser, 2012; Santana \& Silva, 2017; Santos, 2016).

In this sense, with regard to Facebook, the company announced a change in its algorithms in 2018 that favors the formation of filter bubbles. According 
to the social media creator's post, Facebook would prioritize posts from friends, family, and groups over page posting, advertising, and branding, emphasizing that the goal would be to improve people's well-being and happiness by connecting them with whom they like (Zuckerberg, 2018). While justifying this change for positive purposes, such a decision implies a greater potential for control over what each person has access to on Facebook, obligatorily inserting them into bubbles by connecting them only to the ones they like (and what they like).

This form of filtering tends to be understood as invisible, since the service users are mostly unaware of the manipulation to which they are subjected to (Fava \& Pernisa Júnior, 2017; Pariser, 2012). In addition, it is noteworthy that filters tend to be mandatory, since using Facebook (or equivalent social media) makes it difficult to eliminate their action (Pariser, 2012). In this sense, virtual bubbles reduce our contact with diversity, making it difficult for us to develop certain skills, knowledge and critical thinking (Pariser, 2012).

\section{Social influence and persuasion in filter bubbles}

Influence processes are present in practically all interpersonal relationships, whether presential or virtual. However, the media and advertising stand out in using this influence in order to generate changes in the beliefs, attitudes and/or behaviors of individuals, a process called persuasion (Cacioppo, Cacioppo \& Petty, 2018).

Among the several studies that have investigated how media effects occur (Bryant \& Oliver, 2009; Valkenburg, Peter \& Walther, 2016), two aspects should be considered due to the importance of understanding filter bubbles as a social influence mechanism. The first concerns research on media selectivity that has examined, in addition to individual characteristics, questions about how group identification increases social influence by similarity with opinions, values and norms of specific social groups (i.e. family, friends and economic class, among others) to which the person belongs to (Cialdini, 2009; Valkenburg, Peter \& Walther, 2016).

The second aspect concerns media properties, which can be classified as who communicates, what it communicates and through which channels it communicates. Regarding filter bubbles, the dimension of "who communicates" is worth mentioning. In this dimension, the phenomenon of social proof is highlighted, which is mainly used in situations concerning uncertainty about appropriate behavior. In this way, the individual guides his behavior from the way he perceives other people behaving in the same context. Social proof is even more effective when tempered by sympathy and affection (Cialdini, 2009).

In this sense, it appears that filter bubbles favor the influence process through such mechanisms, while Facebook gives priority to posts and content from personal sources (friends) rather than media sources (Zuckerberg, 2018), thus favoring a possible influence due to identification and affection with people who share content that already corroborates to some extent what the individual believes. An example of how this mechanism works was identified in the 2014 presidential elections in Brazil (Brugnago \& Chaia, 2015). The authors detected the formation of ideological groups (through group identification) in the 2014 presidential elections, which became radicalized due to the fact that those with different ideologies became virtually distant.

From this, it can be understood that Facebook's influence on the processes of political radicalization occur more indirectly and imperceptibly, as this service does not need to produce the content, but only filter the unremarkable (social proof) in the user's feed, reducing the possibility of debate and leading to the belief that everyone shares the same opinion, or that it is, in fact, the only possible and true opinion (Brugnago \& Chaia, 2015; Cialdini, 2009).

\section{Political activism and radicalism}

Political activism refers to a set of legal and nonviolent actions for a political cause, being a pathway to social change, while political radicalism can be understood as a set of illegal or violent activities for a political cause (Gloria Filho \& Modesto, 2019; Moskalenko \& McCauley, 2009). In an initial conception of the phenomenon, it was believed that radicalism would be an offshoot of political activism (Moskalenko \& McCauley, 2009). This understanding does not necessarily imply that every activist becomes a radical, but rather that, in general, radical people would have already exhibited activist behavior (Gloria Filho \& Modesto, 2019).

More recently political activism and radicalism have been understood through the Two Pyramid Model (McCauley \& Moskalenko, 2016, 2017), which analyzes radicalization of opinions and of actions, each classified into four levels. In this sense, the pyramid of radicalization of opinions is composed of individuals neutral to a political cause (at the base of the pyramid); individuals who sympathize with a political cause (second level); individuals who believe that their political 
cause may justify violence (third level); and individuals who feel a moral obligation to be violent to defend their political cause (at the top of the pyramid). The radicalization of actions pyramid, on the other hand, is made up of individuals who are doing nothing for a cause or political group (inert - base of the pyramid), those who are engaged in legal political acts for a cause or group (activists - second level), those who are engaged in illegal political acts for a cause or group (radicals - third level) and those who are so engaged in illegal political acts for a cause or group that they attack civilians (terrorists - top of the pyramid).

Although this model comprises a certain continuum between political disinterest and terrorism, the individual will not necessarily go through each level until he or she becomes a terrorist, and may radicalize him or herself by skipping levels, depending on specific situations (Gloria Filho \& Modesto, 2019; McCauley \& Moskalenko, 2017). It is also understood that radical attitudes do not always predict radical behaviors, just as behaviors do not always depend on attitudes. Thus, McCauley and Moskalenko (2017) argue that, while there may be a relationship between the different pyramids, radicalization of opinions rarely leads to radicalization of actions.

Several studies have pointed to variables at different levels of analysis that favor the understanding of what leads us to political activism and radicalism (della Porta, 2018; Ellis et al., 2015; McCauley \& Moskalenko, 2016; Soliman, Bellaj, \& Khelifa, 2016; van Stekelenburg, 2017). Evidence was found, for example, of the relationship between radicalism and disbelief in the legal system of society, disruption or weakening of family and community ties (group factors) and post-traumatic development (Bartlett, Birdwell \& King, 2010; Hobfoll et al., 2007; Johnson et al., 2009; Moskalenko \& McCauley, 2009; Silber \& Bhatt, 2007; Wiktorowicz, 2005). In addition, research has initiated considering the influence of other factors, such as striking emotional experiences and group isolation, which have shown consistent results in terms of increased cohesion and belief in group values and norms due to the lack of other frameworks (Ellis et al., 2015; McCauley, \& Moskalenko, 2016).

In the Brazilian context, Gloria Filho and Modesto (2019) indicate that a factor that may contribute to the explanation of political radicalization in Brazil would be a widespread sense of injustice. According to the authors, people who identify with the left tend to perceive the impeachment of former president Dilma
Roussef and the imprisonment of former president "Lula" as unfair, which may contribute to the radicalization process of this group. Moreover, it can also be considered that disbelief in the Brazilian legal system (with a disbelief about the judiciary and democratic institutions) may have contributed to the strengthening of pro-dictatorship movements and the large number of null or blank votes noted in the last election.

\section{Study Overview}

Given these considerations, the present study aimed to evaluate the influence of the intensity of Facebook use on political radicalism and activism. It was hypothesized $\left(\mathrm{H}_{1}\right)$ that the intense use of Facebook can increase radicalism and activism rates. This hypothesis is based on the understanding that Facebook's filter bubbles favor individuals having access to a larger set of information that comes close to their opinions, and therefore, comes in little contact with information that opposes their beliefs. The bubble can then contribute to radicalism because of this group isolation and scarcity of references that establish a counterpoint (McCauley \& Moskalenko, 2017). Additionally, hypothesis $\left(\mathrm{H}_{2}\right)$ was formulated, where this effect would be partially mediated by the degree of confidence in information consumed on Facebook. In this sense, $\mathrm{H}_{2}$ is based on the understanding that if the individual displays low levels of confidence in the information circulating on Facebook, the intensity of the use of this social media will not be enough to have an effect on political radicalism and activism.

\section{Method}

\section{Participants}

A total of 211 people participated, most of them women $(73 \%)$. Ages ranged from 18 to 80 years old $(M=30.32, S D=12.10)$. Regarding education level, $46.40 \%$ were attending higher education, $26.10 \%$ had completed higher education, $19.90 \%$ had postgraduate education and $6.60 \%$ had attended high school or a lower level at the time of participation. As a participation criterion, all participants should have an active Facebook account at the time they answered the survey.

\section{Instruments}

To assess Facebook use frequency, the Facebook Intensity Scale (Ellison, Steinfield \& Lampe, 2007) was used, in its Portuguese version (Dias, Castillo, \& CastilloLópez, 2017). The measurement consists in a 5-point 
Likert scale, 1 (strongly disagree) and 5 (strongly agree). It was necessary to delete an item from the original scale that corresponded to specific student Facebook use ("I use Facebook to learn more about other people in my class"), as this research was not restricted to this audience. The applied version then consisted of 12 items (i.e. "Facebook is part of my daily activities"; "I would feel bad if Facebook were gone") which were evaluated from their overall score and displayed a satisfactory reliability index $(\alpha=0.80)$.

To assess the degree of confidence in information consumed on Facebook, an adapted version of the Online News Consumption Confidence Scale (Ribeiro, 2016) was applied. The original measure aims to assess the degree of confidence in news that is accessed through internet sites, using a 5-point Likert scale, 1 (strongly disagree) and 5 (strongly agree). This scale was adapted for the present research by replacing the text "this website" with "Facebook" and changing the items indicating the site's responsibility for content production, since this social media, in relation to news, has been used only to reproduce and share news and not produce it. In addition, three items were eliminated from the scale, two due to the difficulty of adapting to Facebook features ("I would share news from this website (by email or social network)" and "I assess the reputation of this website before considering it as a news source") and one because its wording causes confusion concerning Facebook's assessment ("I relate the information presented by a news article on this website with my previous knowledge of the subject"). Thus, the adapted instrument consisted of 18 items (i.e. "I believe Facebook makes use of mechanisms to ensure news accuracy"; "I can form an adequate opinion with the information I read on Facebook about a particular subject"), evaluated from a general score and presenting satisfactory internal consistency ( $\alpha=0.77$ ).

In order to evaluate activism and radicalism rates, the Activism and Radicalism Intention Scale (Moskalenko \& McCauley, 2009), translated and adapted to the Brazilian context (Gloria Filho \& Modesto, 2019) was used. The measurement consists of a Likert scale ranging from 1 (not likely) to 6 (extremely likely). The instrument comprises 10 items classified into two factors, Intent of Activism, items 1 to 5 (i.e. "I would participate in an organization that fights for the legal and political rights of my group"; "I would do voluntary work for an organization that fights for rights) ( $\alpha$ $=0.80$ ), and Intent of Radicalism, items 5 to 10 (i.e. "I would continue to support an organization that fights for my group's political and legal rights even if said organization sometimes resorts to violence", "I would retaliate against members of a group that attacked my group, even if I wasn't sure I was attacking the right group ") ( $\alpha=0.83)$. As with the other measures, satisfactory internal consistency indices were also found.

Additionally, a sociodemographic questionnaire containing questions on gender, age and educational level was used.

\section{Procedures}

The link for access to the online form hosted on Typeform was disclosed through Facebook and WhatsApp, consisting of an initial section containing the Informed Consent Form (ICF), informing the respondent on anonymity, confidentiality, willingness and main research objectives, among other ethical aspects. If the individual agreed to participate, they should respond to the Facebook Intensity Scale, the Online News Consumption Confidence Scale, the Activism and Radicalism Intention Scale, and, finally, report sociodemographic data.

The participants took an average of 8 minutes and 2 seconds to finish answering the entire form. This research was submitted and approved by a Research Ethics Committee, who authorized the data collection.

\section{Data analysis}

Data collection ended after two months of initial disclosure, when the form response rate became less than one response per week. The collected data were then analyzed using the IBM SPSS software, in which linear regressions were performed for the mediation model test.

\section{Results}

Linear regressions were applied in order to analyze the direct influence of the intensity of Facebook use on radicalism and activism indices. As postulated by hypothesis $\left(\mathrm{H}_{1}\right)$, an effect was identified, indicating that the higher the intensity of Facebook use, the higher the activism $\beta=0.25, t(209)=3.76, p<0.001, R^{2}=0.06$ (see Figure 1, ratio B) and radicalism $\beta=0.21, t(209)=$ $3.15, p=0.002, R^{2}=0.04$ rates (see Figure 1, ratio $C$ ).

Then, in order to test the hypothesized mediation model, new linear regressions were applied. A direct relationship between intensity of Facebook use and confidence in online news consumption was identified, $\beta=0.28, t(209)=4.16, p<0.001, R^{2}=0.07$ (see Figure 


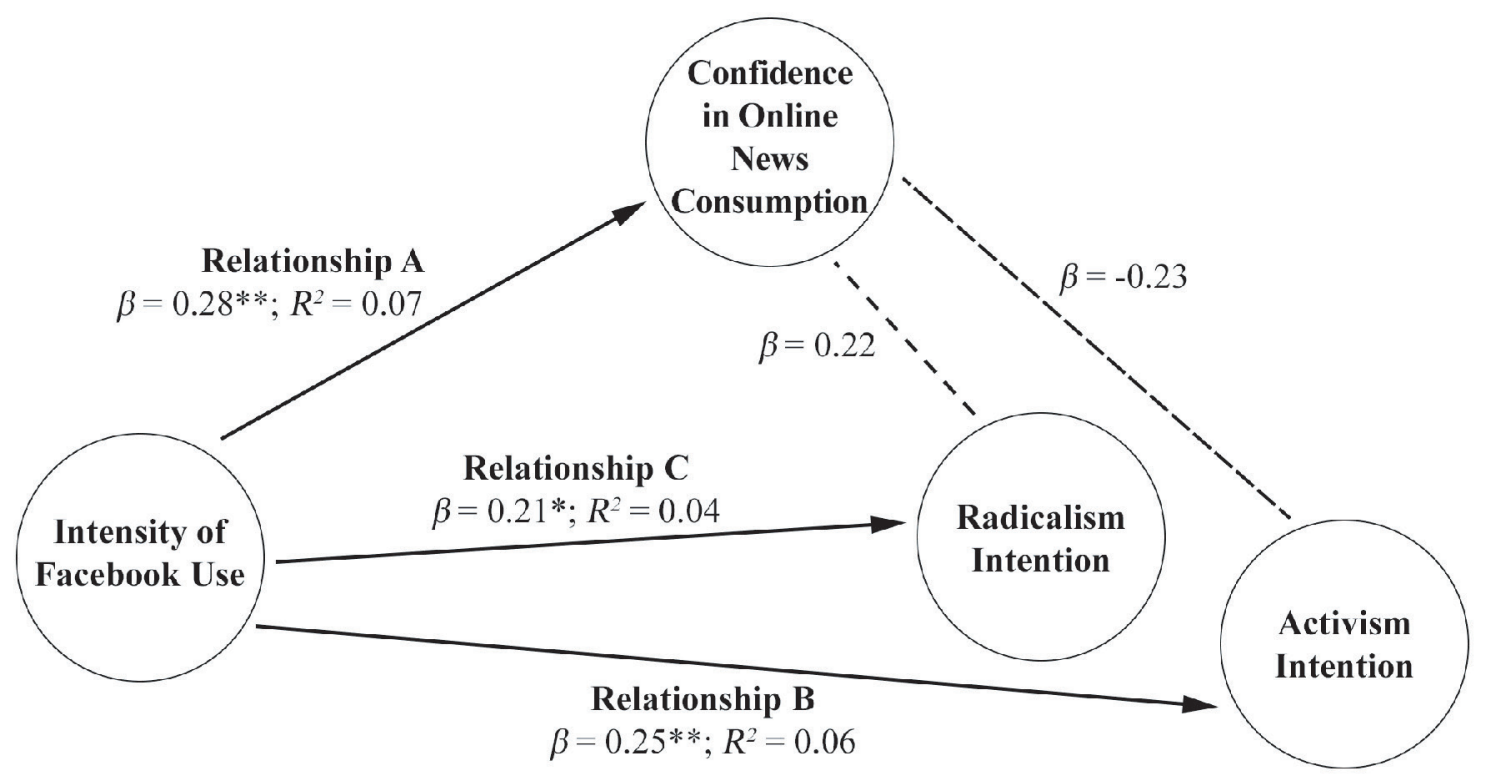

Note. $* p=0,002 ; * * p<0,001$

Figure 1. Statistical parameters of the mediation model for the studied variables

1, A), in other words, the higher the Facebook use, the higher the user's confidence in the news consumption on this social media.

However, unlike the mediation hypothesis $\left(\mathrm{H}_{2}\right)$, no significant relationships were found between confidence in online news consumption with political activism/radicalism, as the results: (a) considering activism intention $(\beta=-0.23, t(209)=-0.33, p=0.75$, see Figure 1); and, (b) considering radicalism intention $(\beta=$ $0.22, t(209)=0.32, p=0.75$, see Figure 1). The data, therefore, indicate the existence of a direct relationship between intensity of Facebook use and political activism and radicalism, with no effect of mediation with the degree of confidence in the consumed information.

\section{Discussion}

The present study aimed to evaluate the influence of the intensity of Facebook use on political activism and radicalism. It was hypothesized $\left(\mathrm{H}_{1}\right)$ that greater Facebook use would lead to greater political activism/ radicalism and $\left(\mathrm{H}_{2}\right)$ that this relationship would be partially mediated by the user's confidence level in the news they access.

The findings corroborated $\mathrm{H}_{1}$, indicating a relationship between Facebook use and political activism/ radicalism. Thus, higher user availability to filter bubbles (greater Facebook use) can influence political positions, as postulated in previous research (Pariser, 2012; Tufekci, 2014). Greater contact between people with similar opinions then seems to contribute to greater activist and radical intentions, due to persuasive mechanisms such as social proof and group identification (Cialdini, 2009; Valkenburg, Peter \& Walther, 2016). In addition, scarce contact with other people and groups (group isolation) can contribute to radical intentions due to the scarcity of references that counteract individual opinions (McCauley \& Moskalenko, 2017).

In addition to a direct effect on activism/radicalism intent, an influence on the intensity of Facebook use on confidence in online news consumption was also observed, which indicates that increased user availability for filter bubbles makes individuals more compliant with information presented on Facebook. One consequence is that those who use this social media more intensely, due to confidence in circulating information, come to believe that most people think the same way (Fava \& Pernisa Júnior, 2017; Pariser, 2012).

Despite the aforementioned direct effects, the mediation hypothesis $\left(\mathrm{H}_{2}\right)$ was not corroborated. No significant relationship was found between confidence in online news consumption and activism and radicalism intentions. The absence of this relationship 
suggests that, regardless of whether the Facebook user relies on the news they are accessing, Facebook use will tend to favor higher activism and radicalism levels. Apparently, posts, opinions and news posted and shared on Facebook need not be based on facts, data or research, allowing these social media to shape user ideology (Brugnago \& Chaia, 2015), even if based on unreliable news. These data are alarming, given that more than half of Brazilians (55\%) believe that the internet consists entirely of Facebook (Mozilla, 2017), and this is the social media where people argue most (Brugnago \& Chaia, 2015; Santos, 2016) and feel the most free to express their views on politics (Santana \& Silva, 2017), indicating Facebook's strength in Brazil. In addition, Brazilians have shown difficulty in distinguishing fake news, sponsored news (advertising) and true news (Santos, 2016).

Based on the findings of this research, further studies can assess the political positioning of social media users (i.e. left, center, right, among others) as a moderator concerning the relationship between Facebook use and activism/radicalism, given that previous studies in Brazil have identified that political positioning influences activism/radicalism intention (Gloria Filho \& Modesto, 2019). Another line of research may involve analyzing the influence of the intensity of Facebook use on the dissemination of fake news, given the evidence reported herein that the intensity of use of this service increases confidence in information circulating on Facebook.

It is important to note that this study also presents some limitations. Although the participant sample did not go through any selection criteria and online application, most respondents were women and people who were at least enrolled in higher education, which does not correspond to the national reality. In addition, the Activism and Radicalism Intention Scale only measures individual intent, and not behavior.

However, we believe that some contributions were possible with this study. Considering the intensifying context of a political radicalism in Brazil and the scarcity of studies on this theme in national psychology (Gloria Filho \& Modesto, 2019), this study presented evidence that contributes to the understanding of the phenomenon. The results can ideally serve to make Facebook users aware of its use, as well as a reflection on social media policies that favor the emergence of filter bubbles that, according to the findings of the present research, contribute to increased political radicalism.

\section{References}

Antunes, B. (2016). A internet de pessoas: a Web 3.0, a exposição dos usuários nas mídias sociais e a polarização de ideias na rede. Anuário Unesco/Metodista de Comunicação Regional, 20, 191-203. doi: 10.15603/2176-0934/aum.v20n20p191-203

Bartlett, J., Birdwell, J., \& King, M. (2010). The edge of violence: A radical approach to extremism. London: Demos.

Brugnago, F., \& Chaia, V. (2015). A nova polarização política nas eleições de 2014: radicalização ideológica da direita no mundo contemporâneo do Facebook. Aurora: revista de arte, mídia e politica, 7(21), 99-129. https://revistas.pucsp.br/aurora/ article/download/22032/16586

Bryant, J., \& Oliver, M. B (Eds.). (2009). Media effects: advances in theory and research ( $3^{\mathrm{a}}$ ed.). New York: Routledge.

Cacioppo, J. T., Cacioppo, S., \& Petty, R. E. (2018). The neuroscience of persuasion: a review with an emphasis on issues and opportunities. Social Neuroscience, 13(2), 129-172. doi: 10.1080/17470919.2016.1273851

Cialdini, R. B. (2009). Influence: science and practice (5 ed.). Boston: Pearson Education.

della Porta, D. (2018). Radicalization: A Relational Perspective. Annual Review of Political Science, 21(1), 461-474. doi: 10.1146/ annurev-polisci-042716-102314

Dias, P. C., Castillo, J. A. G., Castillo-López, A. G. (2017). Preditores do uso do Facebook pelos adolescentes: contributos de um estudo exploratório. Actualidades en Psicología, 31(123), 31-42. doi: 10.15517/ap.v31i123.27450

Ellis, B. H., Abdi, S. M., Horgan, J., Miller, A. B., Saxe, G. N., \& Blood, E. (2015). Trauma and Openness to Legal and Illegal Activism Among Somali Refugees. Terrorism and Political Violence, 27(5), 857-883. doi: 10.1080/09546553.2013.867849

Ellison, N. B., Steinfield, C., \& Lampe, C. (2007). The benefits of Facebook "friends": social capital and college students' use of online social network sites. Journal of ComputerMediated Communication, 12(4), 1143-1168. doi: 10.1111/j.1083-6101.2007.00367.x 
Facebook. (n.d.). About [Facebook Page]. https://www.facebook.com/pg/facebook/ about/?ref=page_internal

Fava, G., \& Pernisa Júnior, C. (2017). Filtro bolha: como tecnologias digitais preditivas transformam a comunicação mediada por computador. Revista ECO-Pós, 16(2), 275-294. https:// revistas.ufrj.br/ index.php/eco_pos/article/view/2277

Gloria Filho, M. C., \& Modesto, J. G. (2019). Morality, activism and radicalism in the brazilian left and the brazilian right. Temas em Psicologia, 27(3), 763-777. doi: 10.9788/TP2019.3-12

Hobfoll, S. E., Hall, B. J., Canetti-Nisim, D., Galea, S., Johnson, R. J., \& Palmieri, P. A. (2007). Refining Our Understanding of Traumatic Growth in the Face of Terrorism: Moving from Meaning Cognitions to Doing what is Meaningful. Applied Psychology: An International Review, 56(3), 345-366. doi: 10.1111/j.1464-0597.2007.00292.x

Johnson, R. J., Canetti, D., Palmieri, P. A., Galea, S., Varley, J., \& Hobfoll, S. E. (2009). A Prospective Study of Risk and Resilience Factors Associated with Posttraumatic Stress Symptoms and Depression Symptoms among Jews and Arabs Exposed to Repeated Acts of Terrorism in Israel. Psychological Trauma: Theory Research, Practice, and Policy, 1(4), 291311. doi: 10.1037/a0017586

McCauley, C. \& Moskalenko, S. (2016). Friction: How Conflict Radicalizes Them and Us. New York: Oxford University Press.

McCauley, C., \& Moskalenko, S. (2017). Understanding Political Radicalization: The Two-Pyramids Model. American Psychologist, 72(3), 205-216. doi: 10.1037/ amp0000062

Moskalenko, S., \& McCauley, C. (2009). Measuring Political Mobilization: The Distinction Between Activism and Radicalism. Terrorism and Political Violence, 21(2), 239-260. doi: 10.1080/09546550902765508

Mozilla. (2017). Internet Health Report v:0.1. https://internethealthreport.org/v01/

Pariser, E. (2012). O filtro invisivel: O que a internet está escondendo de você. Rio de Janeiro: Zahar.

Ribeiro, G. S. (2016). O marketing das noticias: Consumo de informações online, persuasão e confiança (Dissertação de Mestrado não publicada). Programa de Pós-Graduação em Psicologia Social, do Trabalho e das
Organizações, Universidade de Brasília, Brasília, Brasil.

Santana, D. M., \& Silva, N. R. (2017). Polarização política e filtro bolha: sondagens das postagens políticas de estudantes universitários no Facebook. Em $40^{\circ}$ Congresso Brasileiro de Ciências da Comunicaşão. Anais do $40^{\circ}$ Congresso Brasileiro de Ciências da Comunicação - Intercom Júnior - Divisão Temática Comunicação Multimídia, Curitiba, Paraná, Brasil.

Santos, A. (2016). O impacto do Big Data e dos algoritmos nas campanhas eleitorais. Em S. Branco \& C. Teffé, Privacidade em perspectivas (pp. 1-24). Rio de Janeiro: Lumen Juris.

Silber, M. D., \& Bhatt, A. (2007). Radicalization in the West: The homegrown threat. New York: New York City Police Department.

Soliman, A., Bellai, T., \& Khelifa, M. (2016). An integrative psychological model for radicalism: Evidence from structural equation modeling. Personality and Individual Differences, 95, 127-133. doi: 10.1016/j. paid.2016.02.039

Tufekci, Z. (2014). Engineering the public: big data, surveillance and computational politics. First Monday, 19(7). doi: 10.5210/fm.v19i7.4901

Valkenburg, P. M., Peter, J., \& Walther, J. B. (2016). Media effects: Theory and research. $A n-$ nual Review of Psychology, 67. doi: 10.1146/ annurev-psych-122414-033608

van Stekelenburg, J. (2017). Radicalization and Violent Emotions. PS: Political Science \& Politics, 50(4), 936939. doi: 10.1017/S1049096517001020

We are social, \& Hootsuite. (2018). Digital in 2018 in Southern America Part 1 - North (pp. 17-53). https:// www.slideshare.net/wearesocial/digital-in-2018-in-southern-america-part-1-north-86863727

Wiktorowicz, Q. (2005). Radical Islam rising: Muslim extremism in the West. Oxford: Rowman \& Littlefield.

Zuckerberg, M. (2018, 11 de janeiro). One of our big focus areas for 2018 is making sure the time we all spend on Facebook is time well spent [Atualização de status do Facebook]. https://www.facebook.com/zuck/ posts/10104413015393571

Recebido em: 29/01/2019

Reformulado em: 23/08/2019

Aprovado em: 06/11/2019 
About the authors:

Cleno Couto is a psychologist from the Centro Universitário de Brasília (UniCEUB) and currently a master's student in Social, Work and Organizational Psychology at Universidade de Brasília (SWOP / UnB).

ORCID: https://orcid.org/0000-0002-9291-0313

E-mail:ccmn@protonmail.com

João Gabriel Modesto is a psychologist from the Universidade Federal da Bahia (UFBa) with a master's degree and doctorate in Social Psychology from Universidade de Brasilia (UnB). He is currently a professor at the Universidade Estadual de Goiás and the Master's Degree Program in Psychology at Centro Universitário de Brasília (UniCEUB). ORCID: https://orcid.org/0000-0001-8957-7233

E-mail: joao.modesto@ceub.edu.br

\section{Contact:}

SEPN 707/907 - Campus Universitário, Bloco 9, Faculdade de Ciências da Educação e Saúde, Coordenação do Curso de Psicologia

Asa Norte, Brasilia-DF, Brasil

CEP: 70790-075 